Article

\title{
A Referential Methodology for Education on Sustainable Tourism Development
}

\author{
Burcin Hatipoglu ${ }^{1} *$, Bengi Ertuna ${ }^{1}$ and Vinod Sasidharan ${ }^{2}$ \\ ${ }^{1}$ Bogazici University, Department of Tourism Administration / Hisar Kampüs 34342 - Bebek Istanbul, \\ Turkey \\ ${ }^{2}$ San Diego State University, School of Tourism and Hospitality Management / 5500 Campanile \\ Drive, San Diego, CA 92182-4514, USA \\ E-Mails: burcin.hatipoglu@boun.edu.tr; bengie@boun.edu.tr; vsasidha@mail.sdsu.edu
}

* Author to whom correspondence should be addressed; Tel.: +90 212 2596981; Fax: + 90212265 2119

Received: 03 September 2013 / Accepted: 31 October 2013 / Published: 01 November 2013

\begin{abstract}
Sustainable tourism has the potential of contributing to local development while protecting natural environment and preserving cultural heritage. There is a requirement for human resources that can assume effective leadership in sustainable development. The purpose of the international student program described in this paper is to develop and implement an educational methodology to fulfill this need. The study, which was developed and applied by two universities, took place in August 2013 in the study setting of Kastomonu, Turkey. The effectiveness of the program was measured by pre and post surveys using the Global Citizenship Scale developed by Morais and Ogden (2011). The findings document a change in intercultural communication, global knowledge and political voice dimensions of the scale.
\end{abstract}

Keywords: education for sustainable tourism development; global citizenship; study abroad.

\section{Introduction}

The society's preferences are shifting towards having better quality of lives in a more sustainable world. An education system that embraces the values of sustainability starting from pre-school and continuing into university education can act as a "a motor for change" (UNESCO, 2013). Through 
their education students need to gain alternative values, knowledge and skills for integrating sustainability into their daily lives. Oxfam believes that the education of young people for global citizenship will prepare them to meet the challenges of tomorrow (Oxfam, 2013). Higher education institutions should have an active role in this transformation and prepare the future citizens and professionals to face the challenges of $21^{\text {st }}$ century.

Both sustainable development and education for sustainable development (ESD as called by UNESCO) are complex issues. Sustainable development concerns not only the society but also governments, organizations, educators as well as many others. The concept of sustainability is not new, yet it means "many different things to many different people" (McFarlane \& Ogazon, 2011), (Henry, 2009). The different interpretations of the term is partially a result of its multidimensionality (economical, ecological and social) and multidisciplinary nature.

The purpose of this paper is to present a learning methodology in reference to education for sustainable tourism development. After discussing the recent developments in this area, we describe the design of the educational program. The impact of this educational methodology on the leadership qualities for sustainable tourism development, a survey instrument was administered both before and after the program implementation. The Global Citizenship Scale developed by Morais and Ogden (2011) was used in this survey instrument. The changes in global citizenship scores of learners along various dimensions of this scale are reported in the Results and Discussions section.

\section{Education for Sustainable Tourism Development}

Education for sustainable development (ESD) is a new and emerging concept. Similar to sustainable development there are many debates on its definition and correct terminology. Defined in simple terms, it is the process of learning and teaching about how to achieve sustainable development. UNESCO believes better quality of life starts with better education.

UNESCO through its initiative "The Decade for Education for Sustainable Development 2005-2014" (UNDESD) has called all educators into action. The initiative recommends to: 1) promote and improve quality education 2) reorient existing education to address Sustainable Development 3) build public understanding and awareness, and 4) provide practical training (UNESCO, 2013). In the last decade governments have used UNDESD recommendations to integrate sustainable development into their education programs (Vann, Pacheco, \& Motloch, 2006), (Jones, Selby, \& Sterling, 2010). In Scotland, Scottish Executive initiated an action plan titled "Learning for our Future" for the first five years and later continued with a follow-up program called "Learning for Change" (The Scottish Government, 2013). In Australia, the Government explained their approach to UNDESD through "Caring for Our Future" program. Australian Research Institute in Education for Sustainability (ARIES) was established as a research center in order to promote change within the higher education sector (ARIES, 2013).

Numerous higher education institutions around the globe have developed course content and built partnerships to advance ESD. In the UK Universities of Bradford and Plymouth have started with a 
structured approach to curriculum development (Jones, Trien \& Jonathan, 2008). In Australia seven universities have started working together with stakeholders in order to develop course content and design experiential learning experiences (ARIES, 2013). Two universities in Finland and the US built collaborative knowledge base via Facebook for teaching sustainable tourism (Gretzel, Isacsson, Matarrita, \& Wainio, 2011). In the US Arizona State University has a School of Sustainability which offers both undergraduate and graduate degrees of sustainability (McFarlane \& Ogazon, 2011).

Despite the aforementioned examples the integration of sustainable development principles into higher education programs is reported to be slow (Chalkley, Blumhof, \& Ragnarsdottir, 2010), (Tilbury, 2011) with no "systematic treatment for learning" (Henry, 2009) and with much more work to be done (Eames, 2013). Some of the barriers that are specified by scholars are as follows:

1) Lack of motivation and resistance to change on both staff and students (Jones, Trien, \& Jonathan, 2008), (Lozano, 2006), (Lidgren, Rodhe, \& Huisingh, 2006), (McFarlane \& Ogazon, 2011).

2) Mindset (Jones, Trien, \& Jonathan, 2008).

3) Lack of skills/expertise/confidence (Jones, Selby, \& Sterling, 2010).

4) Ethos/culture/organizational structure (Jones, Trien, \& Jonathan, 2008).

5) Crowded curriculum/time constraints (Wilson \& Small, 2013).

The debate on how best to integrate sustainability into higher education has been ongoing for some time among scholars. One thing they all agree is that classical learning techniques will not be suitable for sustainability teaching and that the multidisciplinary and multidimensional nature of sustainability requires a deep learning approach (Blottnitz, 2006) (Jones, Trien, \& Jonathan, 2008). Many recommend a whole systems change for achieving transformation, rather than "add-on approaches to existing structures and curricula" (Sterling, 2004) pg 47. A "sustainability literate person", should be able to conceptualize the relationships between the three dimensions of sustainability and make knowledgeable decisions based on the whole system (Lugg, 2007). The changes should include all stakeholders such as academic directors, professors, students (Lozano, 2006) as well as the changes to the "educational paradigm, purpose, policy and practice" (Sterling, 2004) pg 65. Finding the right pedagogical approach for teaching sustainability and conducting "real world" research is as important as deciding on content (Tilbury, 2011).

Sustainable tourism is widely accepted and advocated as a tool for sustainable development of local communities by international organizations and scientific community (Sharpley, 2000), (Castellani and Sala, 2010). It has the potential of contributing to local development while protecting natural environment and preserving cultural heritage. Achieving these multiple goals seems to require human resources that can assume effective leadership in sustainable development. Canziani et. al (2012) defines sustainability education in tourism as "any level of education or training related to environmental, socio-cultural, and economic issues in the conduct of tourism enterprise and tourism development". 
The International Society of Sustainability Professionals conducted a survey among 400 sustainability coordinators and the results showed that in the near future soft skills like good communication with stakeholders and problem solving are going to be the differentiating factors for professionals. In addition they will be dealing more and more with climate change and energy issues (ISSP, 2010). Scholars in the tourism field agree with the above findings and they acknowledge that future tourism professionals will need "different skills, aptitudes and knowledge to succeed" (Sheldon, Fesenmaier, \& Tribe, 2011). The same scholars are also concerned for the future of tourism education. Literature reveal that there is lack of a coherent learning system (Canziani, Sönmez, Hsieh, \& Byrd, 2012) and lack of resources (Leihy \& Salazar, 2011) for sustainability education in tourism, it is applied in "adhoc way" (Wilson \& Small, 2013) and the "current narrow vocational style" (Sterling, 2004) or "education for jobs and marketability" (McFarlane \& Ogazon, 2011) of tourism does not fit with the demands of the education for sustainability.

There are a few widely referred initiatives about education for sustainable tourism. UNESCO had prepared a "Teaching and Learning for a Sustainable Future" program for the 2002 World Summit on Sustainable Development (updated in 2010). Teaching sustainable tourism was among the 27 modules of its education program (UNESCO, Sustainable Tourism, 2002). In 2008, 5 European and 11 Latin American universities formed the ACES network (Curriculum Greening of Higher Education). Utilizing participatory action research ACES developed a curriculum greening model applicable to various studies (Junyent \& Ciurana, 2008).

A more recent and specific initiative was developed by a group of concerned tourism scholars. 80 educators worked on the initiative between 2007 and 2010 and formed the Tourism Education Futures Initiative (TEFI). TEFI seeks to "fundamentally transform tourism education" and suggests integrating a five value set (ethics, stewardship, knowledge, professionalism, mutuality) into tourism education programs (Sheldon P., Fesenmaier, Woeber, Cooper, \& Antonioli, 2008), (Sheldon, Fesenmaier, \& Tribe, 2011). Global citizenship is seen as essential for addressing the problems of 21 st century by TEFI and their mission statement reads as "TEFI seeks to provide vision, knowledge and a framework for tourism education programs to promote global citizenship and optimism for a better world" (Sheldon, Fesenmaier, \& Tribe, 2011).

Sustainability and global citizenship share some similar aims and values such as care for the larger community and environment. However it is noted that literature that combines sustainability and global citizenship has not much developed (Long, Vogelaar, \& Hale, 2013). Global citizens are people who are aware of the wider world (Oxfam, 2013), and they take responsibility about social and environmental issues both at local level and international level (Hanson, 2010). Morais and Ogden (2011) describe global citizenship in terms of three dimensions.

1. Social responsibility is the perceived level of interdependence and social concern to others, to society and to the environment. The sub-dimensions of social responsibility are listed as global justice and disparities, altruism and empathy and global interconnectedness and personal responsibility. 
2. Global Competence having an open mind while actively seeking to understand others' cultural norms and expectations and leveraging this knowledge to interact, communicate, and work effectively outside one's environment. The sub-dimensions of global competence are selfawareness, intercultural communication and global knowledge.

3. Global Civic Engagement demonstration of action and/or predisposition toward recognizing local, state, national, and global community issues and responding through actions such as volunteerism, political activism, and community participation. The sub-dimensions of global civic engagement are involvement in civic organizations political voice and glocal civic activism.

Many models are being tested around the globe for learning and teaching for sustainable development. Some of the alternative modes of education suggested for sustainability are action learning (Nowak, Rowe, Thomas, \& Klass, 2008), (Jennings, Kensbock, \& Kachel, 2010), outdoors and field study (Long, Vogelaar, \& Hale, 2013), project based learning (Deale \& Barber, 2012), community-based learning and study- abroad programs (Morais \& Ogden, 2011). Currently there are only a few empirical studies on the impact of study abroad programs on sustainability and global citizenship (Tarrant, Lyons, Stoner, Kyle, Wearing, \& Poudyal, 2013), however scholars strongly assert that these experiences will provide students "with a greater sense of intercultural understanding, social justice and equity, self-awareness, and environmental literacy" (Long, Vogelaar, \& Hale, 2013) and will guide them in becoming global citizens (Morais \& Ogden, 2011). Furthermore international collaboration for education for sustainability will enable parties to exchange information and find solutions to sustainability problems that may be transferable (Vann, Pacheco, \& Motloch, 2006).

In brief study abroad programs are where "participants travel to a location as a group with the primary purpose of engaging in a learning experience directly related to that location" (Bodger (1998) taken from (Long, Vogelaar, \& Hale, 2013)).. According Open Doors Report, 273,996 US students have travelled for study abroad programs in 2010/2011. Such programs have become popular and it is expected to become more popular in the near future. The main destinations for US students are UK and Italy and less than $1 \%$ of the total $(2,042)$ have come to Turkey in 2010/2011 (Education, 2012).

The next section describes the educational design of the study and how learning has happened during the program.

\section{Educational Program Design}

The educational program that is presented in this article was specifically developed and implemented by three faculty members to foster learning for sustainable tourism development and improvement in global citizenship behavior in an international setting and has been applied for the first time in year 2013. It is a joint program of the Department of Tourism Administration at Bogazici University, Turkey and School of Tourism and Hospitality Management at San Diego State University, USA. The educational program has two components (Figure1). The first component takes place in a classroom setting before and after travelling to the destination. The field based component, which is part of a study abroad program, focuses on sustainable tourism development at a single destination. The field study took place for twelve days in August 2013 in the study setting of Kastomonu, Turkey. 
Students from both schools have taken part in the study; there were 15 American students and 13 Turkish students. Of all the students, 25 of them were at different stages of their four year undergraduate tourism management education and 3 Turkish students had completed their first year in the sustainable tourism management graduate program. Their knowledge on sustainable tourism development varied as they were at different stages of their programs, but they all had taken at least one course that touched on the principles of sustainable tourism development. Some of the students had already travelled abroad for education (study abroad programs for American students, Erasmus program for Turkish students) and some had never gone out their countries for travel or education purposes.

Travel abroad programs are a form of tourism that should be sustainable themselves. According to Long, Vogelaar, \& Hale (2013) some of the ways of mitigating the negative effects can be through changes made to program logistics, curricular and co-curricular design and program mission and assesment. Accordingly choice of transportation, destination selection, and the choice of food and lodging at the destination are key elements of logistics (Long, Vogelaar, \& Hale, 2013). In our field study program logistics component have been meticulously planned to give the minumum negative effect to the environment and the host communities. One thing that we could not change was the air travel from the San Diego to Istanbul. However, in Istanbul students were given city bus passes and were taken around using the public bus service or by walking. The trip from Istanbul to Kastamonu was done by means of an intercity bus service and students either walked or used the bus service in Kastamonu. The group lodged at a historic Konak (Ottoman style mansion) in Kastamonu, which gave them a deeper understanding of old Ottoman lifestyle and cultural values. Furthermore the group had eaten locally prepared food both at the hotel and also at the sites visited during their stay. They were exposed to local recipes and traditional ways of cooking. In this way they also contributed to the local people economically who have prepared the food.

Canziani et al. (2012) highlight the need for a cohesive learning system for sustainability as well as appropriate learning content. They also recommend to adopt existing decision tools in their entirity rather than adding bits and pieces and concentrate on how to aplly these tools to tourism sustainability contexts (Canziani, Sönmez, Hsieh, \& Byrd, 2012) (pg:8). A holistic learning system should incorporate global communities of practice (of educators, practitioners, and agencies), inputs from learners, goals, implementation, evaluation of the learning, and a feedback loop. In this study we have used their suggested learning model and have adopted it to our educational program. Our model seen in Figure 1 has seven consecutive steps and stakeholders are in the middle, giving and taking feedback from the faculty and learners. The program will be further explained through the seven steps of the learning model.

Step 1 Learning of Core Concepts: Students have been learning about the principles of sustainable tourism development at their individual classroom settings (USA and Turkey). Five months prior to their travel a faculty member from Bogazici University travelled to San Diego and gave a presentation about the context of the field trip and detailed what to expect in Turkey. All the readings, assignments and the assessment criteria were shared with both the American and Turkish students through a course site. The readings included academic articles (Happiness Initiative Articles) as well as destination 
specific economic reports, recent tourism data and strategic tourism plans. In addition Turkish students were given the task of preparing brief reports on social, cultural, natural and historical values of Kastamonu area. These reports were also shared on the course site.

Step 2 Learning Goals: The program aimed to contribute to students' knowledge, skills and aptitudes that will transform them into becoming global citizens and future tourism professionals. The specific goals of the program are:

1. Define sustainable tourism,

2. Attain cross-cultural understanding and engage in bi-national collaborations,

3. Discuss and recommend how sustainable rural tourism development can aid improvement of Quality of Life in a destination.

Step 3 Method of Field Study: Literature emphasizes that concerns for teaching sustainability should be about "what to teach" as well as "how to teach (Jones, Trien, \& Jonathan, 2008). Taking this understanding into consideration, three faculty members worked on the education program content and the suitable learning environment for attaining the program goals over two years. The applied methodology before starting the program had multiple elements; select students for the program, choose field study area and sites to be visited, decide on the topic of the group assignment and suggest a scale, integrate stakeholders to the program and suggest an assignment evaluation methodology.

Student activities were planned so that intercultural understanding happened at several levels. Students were asked to work in bi-national groups of four, which enabled them to understand other nationalities' study methods and work habits. They were also asked to self select their group members after spending a day together, which ensured that they felt comfortable working in their groups. Even though the daily trips were conducted with the entire student group, teams were encouraged to prepare their questions beforehand and interview the stakeholders with their group members.

Sustainable tourism development principles were woven into the group assignment that was to be presented at the end of the field trip. Students were asked to "Examine how sustainable rural tourism development could be achieved in Kastamonu province, through the improvement of Quality of Life of the region's residents". Students were recommended to use Seattle Area Happiness Initiative to explain quality of life improvements in Kastamonu region.

In 1972 the King of Bhutan declared the goal of happiness is more important than the goal of wealth and the term "gross national happiness" was born. Later Bhutan developed a survey with help from UNDP and scientists. Consecutively the shortened version of the survey was applied in Brazil and Victoria, BC in 2008. Sustainable Seattle had been working on a set of indicators since 1993 but in 2010 they took a new approach and adopted shortened version of Bhutan's survey. The Happiness Initiative measures happiness along nine dimensions of wellbeing (Seattle, 2011).

- Ecological Vitality is the quality of local and global environment with access to nature

- Governance is about confidence in each level of government and freedom from discrimination

- Material Well-Being addresses satisfaction with financial situation and financial future

- Psychological Well-Being addresses issues of self-esteem, autonomy and sense of purpose. 
- Physical Health is about physical health and experience of disability or long-term illness.

- Time and Work-Life Balance is about senses of stress, control over their lives and overwork

- Social Vitality and Connection is combination of interpersonal trust, social support and community participation

- Education how they participate in educational activities, discrimination

- Cultural Vitality how they participate in arts and culture, sport and recreation activities.

The next section explains how each site in Kastamonu was selected using the nine dimensions of the Initiative.

Step 4 Site Specific Content: Two faculty members of Bogazici University that had previously visited Kastamonu for research purposes have specifically chosen the region for field study. The area is rich in cultural, natural and historical resources and yet tourism is underdeveloped. Migration to larger cities for work and education is an ongoing concern and development of tourism is seen as a panacea to this problem. Kastamonu is one of the areas designated for tourism development according to Tourism Strategy 2023 Report of the Ministry of Culture and Tourism.

The daily trips and visits in Kastamonu area were planned to cover Seattle Area Happiness Initiative indicators in line with contextual characteristics of the city (human, cultural, natural, historical resources). Consultation with the stakeholders started one year prior to the field trip in Kastamonu. From the start they have taken part in planning the field trip and its components. A typical day included the following events:

- Meet with Tasköprü Chamber of Agriculture and take part in the garlic harvest

- Lunch at a village house with the community

- Visit to the Municipality

- Visit archeological site at Pompeipolis, meet with the archeologists and the site coordinator

- Visit Taskopru Festival area (a local festival held after the garlic harvest)

- Dinner with the excavation team

Each day combined multiple elements of the Seattle Area Happiness Initiative indicators. The program shown above was planned to experience 1) Material Wellbeing (garlic harvest as an economic activity), 2) Governance (meeting with the Municipality) and 3) Cultural Vitality (thousands of local participated in the Taskopru Festival area) in the area.

After the completion of the daily visits students had taken a well rounded view of the Life Quality of Kastamonu residents and had come into contact with multiple stakeholders involved in tourism activities. The next section summarizes their learning routines.

Step 5 Process and Learning: After arriving in Istanbul, students spent two full days with the guidance of the three faculty members involved in the project and two others who have joined from Bogazici University. As a part of the Istanbul portion of the program students were exposed to cultural pluralism in Turkey, from both historical and contemporary socio-political perspectives. The Istanbul experience established the academic foundation for the students to engage in enchanted, meaningful cross-cultural interactions in preparation for their field study. 
On the way from Istanbul to Kastamonu the group spent half a day at the city of Safranbolu. This visit gave them the opportunity to experience a city that is on the UN World Heritage list that had developed cultural tourism for the last twenty years (UNESCO, City of Safranbolu, 2013). Later during the week students were asked to make comparisons among the tourism development in Safranbolu and Kastamonu.

After arriving in Kastamonu students were asked to form their groups and start working together as a group. Faculty was observing group interactions from a distance, offering guidance only when needed. During the learning for sustainable development the emphasis should be on "participation, appreciation and self-organization" rather than "fragmentation, control and manipulation" (Sterling, 2004) pg 50.

Briefings about Kastamonu were provided by the Bogazici University students during site visits. "Learning for Our Future" program of Scotland Government has identified 1) joined up thinking, 2) participative working and 3) reflective practice as essential set of skills for learning for sustainable development (The Scottish Government, 2013). Based on this understanding groups were set free to organize their learning experiences. They decided how they used their afternoon discussion and reflection hours and which kinds of information they needed to collect during their trips.

The types of student learning observed by the faculty were as follows:

Observe local community traditions, food preparation, economic activities, religious practices, and arts and folkloric dances

Ask questions to stakeholders and community members

Participate in a local festival and community service

Discuss issues with group members

Reflect alone

The last step of their field trip learning experience was the presentation of their group findings, which is explained in the next section.

Step 6 Results and Presentations: Groups were asked to present their findings in a presentation format with the participation of all group members. On the final day of the field trip all the stakeholders involved in the project were invited to listen to and evaluate the presentations.

Groups were given a total of twenty minutes, of which included the presentation in English, and a summary Turkish and question and answer. Students were asked to answer the below questions in their presentations:

1. Brief overview of what each indicator means and how it connects to sustainability in the Kastamonu community.

2. Describe ways in which residents can achieve sustainability through tourism development in the Kastamonu community.

3. List interesting sustainability related facts in the Kastamonu community. 
Stakeholders were asked to evaluate the students on the quality of their presentations in respect to oral presentations, description of core issues, application to tourism, the group recommendations and the visuals. During the question and answer section feedback was provided to the groups.

The faculty members and the stakeholders met after the completion of presentations and discussed the results of the field study. This discussion and the feedback received is expected to aid in the planning the next year's field study program.

Step 7 Evaluation of the Field Study: After students go back to their universities they enroll in a sustainable tourism course that is given by the organizing faculty members. They will discuss the findings of their field study and start generating recommendations and projects for the region.

Role of Stakeholders: Stern (2004) asserts that any educational system should be seen as a sub-system of the wider society. In this regard our program which was shaped by the input of community members has become part of the Kastamonu community. The field study was covered by the local newspapers widely and has found itself a place on the numerous web pages of the city.

The stakeholders that were involved in the field study included hotel owners and tourism entrepreneurs, Kastamonu Governor's Office, Kastamonu Tourism and Culture Department, Governor's European Union Project Unit, Regional Development Agency, Chamber of Commerce, environmental activists, Ecotourism Association, local university members and various municipalities. Collaboration will enable "exchange of information and learning of common worldviews" as well as "support a sustainability transition"(Henry, 2009). In their study Padurean and Maggi noted that tourism students find their universities are less involved with the community, which is something of value for the industry and the students (Padurean \& Maggi, 2011). The inclusion of a diverse group of stakeholders in our study and their involvement in the planning, execution and evaluation stages of the field study ensured to create a community based experience for the students.

In double loop learning there are positive feedback loops between the system and its environment and they both attain a new state (Stern, 2004: pg 55). In our study the change has happened through interactions with the environment and the stakeholders and both the learners and stakeholders have changed through exposure to each other (Figure 1, double sided arrows signify this change). 


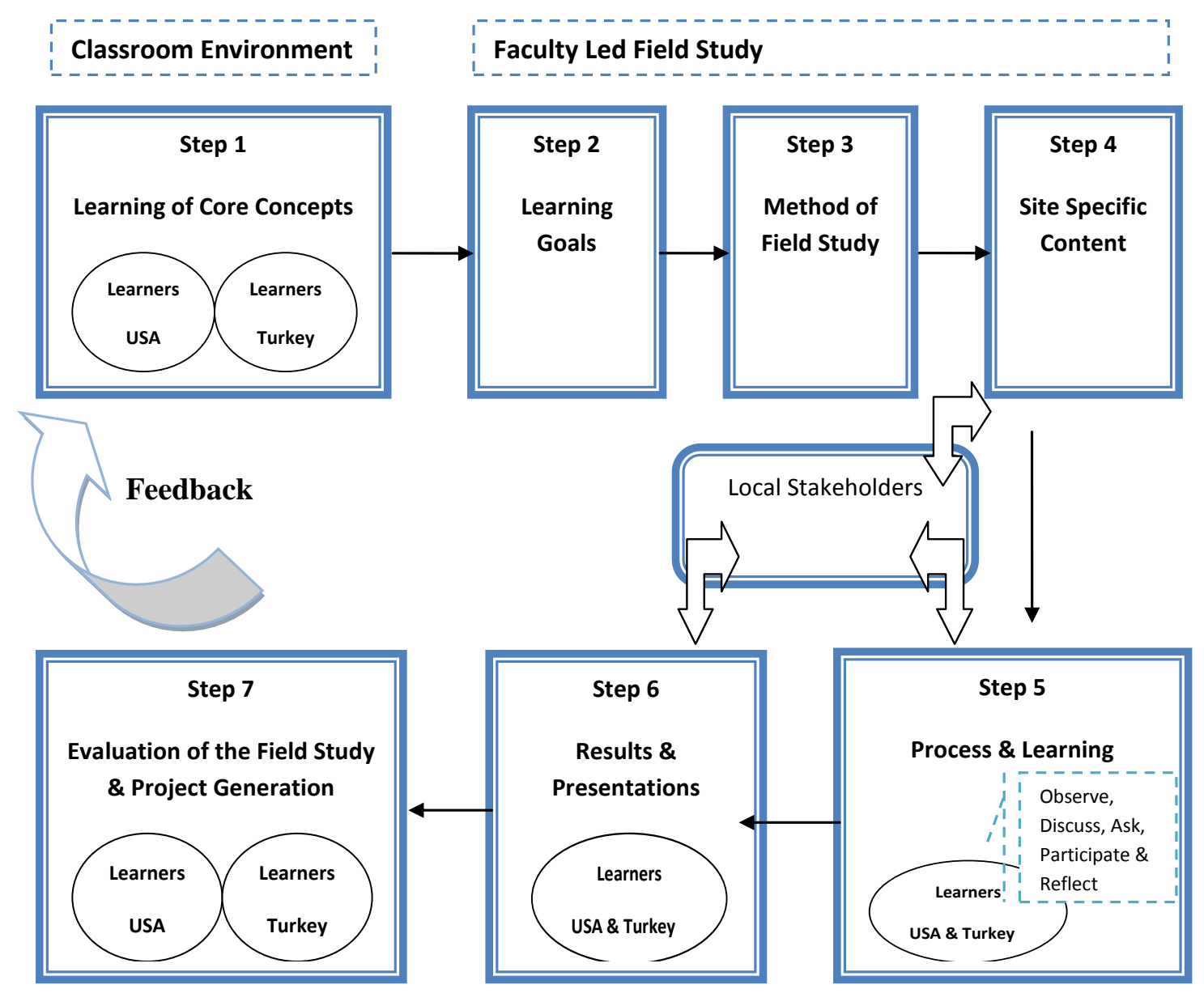

Adopted from (Canziani, Sönmez, Hsieh, \& Byrd, 2012).

Figure 1: A Learning Methodology for Education on Sustainable Tourism Development and Global Citizenship

\section{Results and Discussion}

To assess the impact of this educational methodology on the leadership qualities for sustainable tourism development, pre-post design was used in which students completed a survey instrument on the first day (pre-test) and last day (post-test) of the program in Kastamonu. The Global Citizenship Scale developed by Morais and Ogden (2011) was used in this survey instrument. Surveys were completed by all 28 students voluntarily. Differences in the pre-test and post-test scores were analyzed using paired samples t-test using SPSS version 21. Statistics relating to the pre and post scores of the learners on all the dimensions and items of the global citizenship scale together with the paired t-test statistics for comparing the change in pre and post scores are provided in the appendix.

The results indicate a change in global citizenship score of the students along some dimensions of this score, as well as their conceptions about sustainable tourism development. Using significance level set at $\mathrm{p}<0.01$ there were significant changes at two sub-dimensions of the scale. Students felt that after completing the program they were comfortable expressing their views regarding a pressing global problem in front of a group of people and they were able to communicate in different ways with people from different cultures (Table 1). One of the learning aims of the program was to attain cross cultural 
understanding and engage in bi-national collaborations. The results confirm that this aim was achieved through "Process and Learning" and "Results and Presentations" steps of the program. During these steps students were given plenty of opportunities to interact with the community as well as make presentations of their findings in front of the stakeholders.

Using significance level set at $\mathrm{p}<0.05$ and at $\mathrm{p}<0.1$ some other significant changes were noted that supported changes in global justice and disparities, involvement in civic organizations and political voice (Table 1). Overall as a result of the program the greatest change had happened in the Global Competence dimension and specifically in the Intercultural Communication and Global Knowledge sub-dimensions. These results underlined the importance of the educational program design in the attainment of goals. In our program, the positioning of the stakeholders have ensured the confidence created in the students in communicating with stakeholders, which is reported to be an essential skill for future tourism professionals (ISSP, 2010).

Table 1: Significant Changes in Dimensions of Global Citizenship Scores

\begin{tabular}{|c|c|c|c|}
\hline & $\begin{array}{l}\text { Paired } \\
\text { Difference } \\
\text { Mean }\end{array}$ & t-score & $\begin{array}{l}\text { Sig. }(2- \\
\text { tailed) }\end{array}$ \\
\hline $\begin{array}{l}\text { Social Responsibility: Global Justice and Disparities } \\
\text { It is OK if some people in the world have more } \\
\text { opportunities than others. }\end{array}$ & 250 & 1,760 & ,090 \\
\hline Global Competence: Intercultural Communication & & & \\
\hline $\begin{array}{l}\text { I often adapt my communication style to other } \\
\text { people's cultural background. }\end{array}$ &,- 393 & $-2,645$ & ,013 \\
\hline $\begin{array}{l}\text { I am able to communicate in different ways with } \\
\text { people from different cultures. }\end{array}$ &,- 429 & $-3,057$ & ,005 \\
\hline Global Competence: Global Knowledge & & & \\
\hline $\begin{array}{l}\text { I am informed of current issues that impact } \\
\text { international relationships. }\end{array}$ &,- 222 & $-2,280$ &, 031 \\
\hline $\begin{array}{l}\text { I feel comfortable expressing my views regarding a } \\
\text { pressing global problem in front of a group of people. }\end{array}$ &,- 593 & $-3,309$ & ,003 \\
\hline $\begin{array}{l}\text { Global Civic Engagement: Involvement in Civic } \\
\text { Organizations } \\
\text { Over the next } 6 \text { months, I plan to do volunteer work } \\
\text { to help individuals and communities abroad. }\end{array}$ &,- 357 & $-2,173$ & ,039 \\
\hline Global Civic Engagement: Political Voice & & & \\
\hline $\begin{array}{l}\text { Over the next } 6 \text { months, I will contact a newspaper or } \\
\text { radio to express my concerns about global } \\
\text { environmental, social, or political problems. } \\
\text { Over the next } 6 \text { months, I will display and/or wear } \\
\text { badges/stickers/signs that promote a more just and } \\
\text { equitable world. }\end{array}$ &,- 357 & $-2,714$ & ,011 \\
\hline
\end{tabular}


The dimensions in which the scores of the learners changed significantly match closely with the learning goals adopted and the methodology employed in the design of the educational program. Sustainability principles were embedded to the program through the nine dimensions of Seattle Happiness Initiative, where sites to be visited, stakeholders to be included and activities to be incorporated were determined along these dimensions in the design phase of the program. The results reveal that observed changes correspond to the program design and reflect the importance of the design phase on the effectiveness of the educational programs.

The results suggest that the design of the educational program needs to be contextual. The educational program presented in this paper incorporated the contextual characteristics of the study area, problems of sustainable development as well as specific challenges in developing tourism activity. This contributed to the effectiveness of the program by integrating tourism development with sustainability concepts. Consequently, contextual characteristics of a given study area should be incorporated into design of educational programs in other settings.

The changes observed in learners' scores reflect the local emphasis adopted in the design of the program. Accordingly, no significant changes were observed in global civic engagement dimension of the global citizenship scores of the learners. In future studies, local emphasis can be extended in a way to include a global dimension to improve the effectiveness of the educational methodology.

\section{Acknowledgments}

We would like to thank all the stakeholders that have taken part in this educational program.

\section{Conflict of Interest}

The authors declare no conflict of interest.

\section{References and Notes}

ARIES. (2013, October 05). Education for Sustainability. Retrieved 2013, from Macquire University: http://aries.mq.edu.au/publications/aries/efs_brochure/pdf/efs_brochure.pdf

Blottnitz, H. V. (2006). Promoting active learning in sustainable development:experiences from a 4th year chemical engineering course. Journal of Cleaner Production , 14, 916-923.

Boyle, A. R. (2012). Teaching sustainability: A pathway forward for tourism education. 12th Australasian Campuses Towards Sustainability (ACTS) Conference. Brisbane, Queensland: http://www.acts.asn.au/index.php/2012-acts-conference/proceedings/.

Canziani, B. F., Sönmez, S., Hsieh, Y., \& Byrd, E. T. (2012). A learning theory framework for sustainability education in tourism. Journal of Teaching in Travel \& Tourism , 12 (1), 3-20.

Castellani, V., \& Sala, S. (2010). Sustainable performance index for tourism policy development. Tourism Management, 31 (6), 871-880. 
Chalkley, Blumhof, \& Ragnarsdottir. (2010). Geography Earth and Environmental Sciences: A suitable home for ESD? In P. Jones, D. Selby, \& S. Sterling, Sustainability Education: Perspectives and Practice Across Higher Education (pp. 93-108). London: Earthscan.

Deale, \& Barber. (2012). How important is sustainability education to hospitality programs? Journal of Teaching in Travel \& Tourism , 12, 165-187.

Eames, M. T. (2013). At the crossroads: Teaching sustainability at university. A comparison of experiences from Kingston and Olderburg Universities. Inside E. T. Comby, Developing Sustainability (s. 77-94). Istanbul,Turkey: Istanbul Bilgi University Press.

Education, I. O. (2012). Top 25 Destinations of U.S. Study Abroad Students, 2009/10 -2010/11. (O. D. Exchange, Ed.) Retrieved October 05 05, 2013, from http://www.iie.org/opendoors.

Gretzel, U., Isacsson, A., Matarrita, D., \& Wainio, E. (2011). Teaching Based on TEFI Values: A Case Study. Journal of Teaching in Travel \& Tourism , 11 (1), 94-106.

Hanson, 1. (2010). Global citizenship, global health, and the internationalization of curriculum: A study of transformative potential. Journal of Studies in International Education , 14 (1), 70-88.

Henry, A. D. (2009). The challenge of learning for sustainability: A prolegomenon to theory. Human Ecologt Review , 16 (2), 131-139.

ISSP. (2010). The Sustainability Professional:2010 Competency Survey Report. Professionals, International Society of Sustainability.

Jennings, G., Kensbock, S., \& Kachel, U. (2010). Enhancing 'Education About and ForSustainability' in a Tourism Studies Enterprise Management Course: An Action Research Approach. Journal of Teaching in Travel \& Tourism , 10, 163-191.

Jones, P., Selby, D., \& Sterling, S. (2010). Introduction. P. Jones, D. Selby, \& S. Sterling içinde, Sustainability Education: Perspectives and Practice Across Higher Education (s. 1-17). London: Earthscan.

Jones, P., Trien, C., \& Jonathan, R. (2008). Embedding Education for Sustainable Development in higher education: A case study examining common challenges and opportunities for undergraduate programmes. International Journal of Educational Research , 47 (6), 341-350.

Junyent, M., \& Ciurana. (2008). Education for sustainability in university studies: A model for reorienting the curriculum. British Educational Research Journal, 763-782.

Leihy, P., \& Salazar, J. (2011). Education for sustainability in university curricula: Policies and practice. University of Melbourne: (Prepared for Sustainablility Victoria) Centre for the Study of Higher Education.

Lidgren, A., Rodhe, H., \& Huisingh, D. (2006). A systemic approach to incorporate sustainability into university courses and curricula. Journal of Cleaner Production, 14 (9-11), 797-809.

Long, J., Vogelaar, A., \& Hale, B. W. (2013). Toward sustainable educational travel. Journal of Sustainable Tourism, http://dx.doi.org/10.1080/09669582.2013.819877. 
Lozano, R. (2006). Incorporation and institutionalization of SD into universities: breaking through barriers to change. Journal of Cleaner Production , 14, 787-796.

Lugg, A. (2007). Developing sustainability-literate citizens through outdoor learning:possibilities for outdoor education in Higher Education. Journal of Adventure Education \& Outdoor Learning , 7 (2), 97-112.

McFarlane, D., \& Ogazon, A. (2011). The challanges of sustainability education. Journal of Multidisciplinary Research, 3 (3), 81.

Morais, D. B., \& Ogden, A. C. (2011). Initial development and validation of the Global Citizenship Scale. Journal of Studies in International Education, 15 (5), 445-466.

Nowak, M., Rowe, A. L., Thomas, G., \& Klass, D. (2008). Weaving sustainability into business education. Journal of the Asia Pacific Centre for Environmental Accountability, 14 (2), 20-34.

Oxfam. (2013, October 05). Why is education for global citizenship? Retrieved October 05, 2013, from Global Citizenship:

http://www.oxfam.org.uk/ /media/Files/Education/Global\%20Citizenship/education_for_global_citize nship_a_guide_for_schools.ashx

Padurean, L., \& Maggi, R. (2011). TEFI Values in tourism education: A comparative analysis. Journal of Teaching in Travel \& Tourism, 24-37.

Seattle, H. R. (2011). Happiness Report Card for Seattle. Retrieved March 2013, from The Happiness Initiative: http://www.happycounts.org/wp-system/wp-content/uploads/downloads/2011/11/SeattleHappiness_Report_Card-2011.pdf

Sharpley, R. (2000). Tourism and sustainable development: Exploring the theoretical divide. Journal of Sustainable Tourism , 8 (1), 1-19.

Sheldon, P. J., Fesenmaier, D. R., \& Tribe, J. (2011). The tourism education futures initiative (TEFI): Activating Change in Tourism Education. Journal of Teaching in Travel \& Tourism, 2-23.

Sheldon, P., Fesenmaier, D., Woeber, K., Cooper, C., \& Antonioli, M. (2008). Tourism education futures, 2010-2030: Building the capacity to lead. Journal of Teaching in Tourism and Travel , 61-68.

Sterling, S. (2004). Higher education, sustainability, and the role of systemic learning. In P. B. Corcoran, \& A. E. J.Wals, Higher education and the challenge of sustainability: Problematics, Promise, and Practice (pp. 47-70). Hingham, MA, USA: Kluwer Academic Publishers.

Tarrant, M. A., Lyons, K., Stoner, L., Kyle, G. T., Wearing, S., \& Poudyal, N. (2013). Global citizenry, educational travel and sustainable tourism: evidence from Australia and New Zealand. Journal of Sustainable Tourism, 1-20.

Tilbury, D. (2011). Higher Education for Sustainability: A Global Overview of Commitment and Progress. In G. U. (GUNI), Higher Education's Commitment to Sustainability: From Understanding to Action (pp. 1-21). Paris: Palgrave Macmillan. 
The Scottish Government (2013, October). Learning for Change: Scotland's Action Plan for the Second Half of the UN Decade of Education for Sustainable Development. Retrieved October 02, 2013, from http://www.scotland.gov.uk/Publications/2010/05/20152453/2

UNESCO. (2013). United Nations Decade of Education for Sustainable Developement 2005-2014 Retrieved October 2013, from http://unesdoc.unesco.org/images/0014/001416/141629e.pdf

UNESCO. (2013, October). City of Safranbolu. UN World Heritage List: Retrieved October 03, http://whc.unesco.org/en/list/614.

UNESCO. (2002). Sustainable Tourism. Retrieved October 05, 2013, from Teaching and Learning for a Sustainable Future: http://www.unesco.org/education/tlsf/mods/theme_c/mod16.html

Vann, J., Pacheco, P., \& Motloch, J. (2006). Cross-cultural education for sustainability: Development of an introduction to sustainability course. Journal of Cleaner Production, 14, 900-905.

Wilson, E., \& Small, J. (2013). TEFI 6, June 28-80,2012,Milan, Itlay: Transformational leadership for tourism education. Journal of Teaching in Travel \& Tourism , 13 (2), 202-206.

(C) 2011 by the authors; licensee MDPI, Basel, Switzerland. This article is an open access article distributed under the terms and conditions of the Creative Commons Attribution license (http://creativecommons.org/licenses/by/3.0/). 


\section{Appendix: Paired Samples Statistics - Pre- and Post-Program}

Scores

\begin{tabular}{|c|c|c|c|c|c|c|}
\hline & & Mean & \begin{tabular}{c|} 
Std. \\
Deviation
\end{tabular} & \begin{tabular}{|c|} 
Paired \\
Difference \\
Mean \\
\end{tabular} & t-score & $\begin{array}{l}\text { Sig. }(2- \\
\text { tailed) }\end{array}$ \\
\hline \multirow{2}{*}{$\begin{array}{l}\text { I think that most people around the world get } \\
\text { what they are entitled to have }\end{array}$} & pre- & 1,86 &, 891 & \multirow[t]{2}{*}{, 107} & \multirow[t]{2}{*}{,682 } & \multirow[t]{2}{*}{, 501} \\
\hline & post- & 1,75 &, 887 & & & \\
\hline \multirow{2}{*}{$\begin{array}{l}\text { It is OK if some people in the world have more } \\
\text { opportunities than others. }\end{array}$} & pre- & 2,25 &, 752 & \multirow[t]{2}{*}{250} & \multirow[t]{2}{*}{1,760} & \multirow[t]{2}{*}{,090 } \\
\hline & post- & 2,00 & ,943 & & & \\
\hline \multirow{2}{*}{$\begin{array}{l}\text { I think that people around the world get the } \\
\text { rewards and punishments theydeserve. }\end{array}$} & pre- & 1,81 &, 681 & \multirow[t]{2}{*}{,- 037} & \multirow[t]{2}{*}{,- 214} & \multirow[t]{2}{*}{832} \\
\hline & post- & 1,85 &, 770 & & & \\
\hline \multirow{2}{*}{$\begin{array}{l}\text { In times of scarcity, it is sometimes necessary to } \\
\text { use force against others to getwhat you need. }\end{array}$} & pre- & 1,86 & ,970 & \multirow[t]{2}{*}{,214 } & \multirow[t]{2}{*}{1,362} & \multirow[t]{2}{*}{, 184} \\
\hline & post- & 1,64 & ,951 & & & \\
\hline \multirow[t]{2}{*}{ The world is generally a fair place. } & pre- & 1,89 &, 567 & \multirow[t]{2}{*}{, 071} & \multirow[t]{2}{*}{,570 } & \multirow[t]{2}{*}{,573 } \\
\hline & post- & 1,82 &, 548 & & & \\
\hline \multirow{2}{*}{$\begin{array}{l}\text { No one country or group of people should } \\
\text { dominate and exploit others in the world. }\end{array}$} & pre- & 4,25 & 1,143 & \multirow[t]{2}{*}{,- 036} & \multirow[t]{2}{*}{,- 126} & \multirow[t]{2}{*}{,901 } \\
\hline & post- & 4,29 & 1,013 & & & \\
\hline \multirow{2}{*}{$\begin{array}{l}\text { The needs of the worlds' most fragile people are } \\
\text { more pressing than my own. }\end{array}$} & pre- & 3,59 & 1,010 & \multirow[t]{2}{*}{,- 148} & \multirow[t]{2}{*}{,- 941} & \multirow[t]{2}{*}{,355 } \\
\hline & post- & 3,74 & ,764 & & & \\
\hline I think that many people around the world are & pre- & 1,82 &, 772 &,- 036 &,- 328 &, 745 \\
\hline & post- & 1,86 & ,803 & & & \\
\hline I respect and am concerned with the rights of all & pre- & 4,30 &, 724 & , 148 & 1,072 & 294 \\
\hline & post- & 4,15 & ,718 & & & \\
\hline Developed/Developing nations have the & pre- & 3,43 &, 879 & 107 &, 550 &, 587 \\
\hline $\begin{array}{l}\text { obligation to make incomes around the world as } \\
\text { equitable as possible }\end{array}$ & post- & 3,32 & 1,020 & & & \\
\hline American/Turkish people should emulate the & pre- & 4,11 & ,786 &,- 107 &,- 769 & ,449 \\
\hline $\begin{array}{l}\text { more sustainable and equitable behaviors of other } \\
\text { developed/developing countries }\end{array}$ & post- & 4,21 &, 738 & & & \\
\hline I do not feel responsible for the world's inequities & pre- & 2,64 & 1,062 & 0,000 & 0,000 & 1,000 \\
\hline & post- & 2,64 & 1,193 & & & \\
\hline I think in terms of giving back to the global & pre- & 3,71 & ,937 &,- 036 &,- 238 & ,813 \\
\hline & post- & 3,75 & ,799 & & & \\
\hline I am confident that I can thrive in any culture or & pre- & 3,61 & 1,066 &,- 214 &,- 902 & ,375 \\
\hline & post- & 3,82 & ,945 & & & \\
\hline I know how to develop a place to help mitigate a & pre- & 3,36 &, 731 &,- 143 &,- 891 & ,381 \\
\hline & post- & 3,50 &, 745 & & & \\
\hline I know several ways in which I can make a & pre- & 3,43 & ,920 &,- 107 &,- 682 & 501 \\
\hline $\begin{array}{l}\text { difference on some of this world's most } \\
\text { worrisome problems. }\end{array}$ & post- & 3,54 & ,793 & & & \\
\hline I am able to get other people to care about global & pre- & 3,75 & ,967 &,- 250 & $-1,567$ & 129 \\
\hline & post- & 4,00 &, 609 & & & \\
\hline
\end{tabular}

\section{\begin{tabular}{l|l|l}
$p<0.01$ & $p<0.05$ & $p<0.1$
\end{tabular}}




\begin{tabular}{|c|c|c|c|c|c|c|}
\hline & & Mean & $\begin{array}{c}\text { Std. } \\
\text { Deviation }\end{array}$ & \begin{tabular}{|c|} 
Paired \\
Difference \\
Mean \\
\end{tabular} & t-score & $\begin{array}{l}\text { Sig. }(2- \\
\text { tailed) }\end{array}$ \\
\hline \multirow{2}{*}{$\begin{array}{l}\text { I unconsciously adapt my behavior and } \\
\text { mannerisms when I am interacting with people of } \\
\text { other cultures. }\end{array}$} & pre- & 3,96 &, 744 & \multirow[t]{2}{*}{,- 036} & \multirow[t]{2}{*}{,- 328} & \multirow[t]{2}{*}{,745 } \\
\hline & post- & 4,00 &, 720 & & & \\
\hline \multirow{2}{*}{$\begin{array}{l}\text { I often adapt my communication style to other } \\
\text { people's cultural background }\end{array}$} & pre- & 3,71 & ,763 & \multirow[t]{2}{*}{,- 393} & \multirow[t]{2}{*}{$-2,645$} & \multirow[t]{2}{*}{,013 } \\
\hline & post- & 4,11 & ,737 & & & \\
\hline \multirow{2}{*}{$\begin{array}{l}\text { I am able to communicate in different ways with } \\
\text { people from different cultures. }\end{array}$} & pre- & 3,79 &, 630 & \multirow[t]{2}{*}{,- 429} & \multirow[t]{2}{*}{$-3,057$} & \multirow[t]{2}{*}{,005 } \\
\hline & post- & 4,21 & ,499 & & & \\
\hline \multirow[t]{2}{*}{ I am fluent in more than one language. } & pre- & 2,71 & 1,410 & \multirow[t]{2}{*}{,- 179} & \multirow[t]{2}{*}{$-1,307$} & \multirow[t]{2}{*}{,202 } \\
\hline & post- & 2,89 & 1,397 & & & \\
\hline \multirow{2}{*}{$\begin{array}{l}\text { I welcome working with people who have } \\
\text { different cultural values from me. }\end{array}$} & pre- & 4,52 & ,580 & \multirow[t]{2}{*}{, 148} & \multirow[t]{2}{*}{1,162} & \multirow[t]{2}{*}{,256 } \\
\hline & post- & 4,37 & ,492 & & & \\
\hline \multirow{2}{*}{$\begin{array}{l}\text { I am able to mediate interactions between people } \\
\text { of different cultures by helpingthem understand } \\
\text { each other's values and practices. }\end{array}$} & pre- & 3,68 & 670 & \multirow[t]{2}{*}{,- 357} & \multirow[t]{2}{*}{$-2,423$} & \multirow[t]{2}{*}{,022 } \\
\hline & post- & 4,04 & ,508 & & & \\
\hline \multirow{2}{*}{$\begin{array}{l}\text { I am informed of current issues that impact } \\
\text { international relationships. }\end{array}$} & pre- & 3,59 & ,797 & \multirow[t]{2}{*}{,- 222} & \multirow[t]{2}{*}{$-2,280$} & \multirow[t]{2}{*}{,031 } \\
\hline & post- & 3,81 &, 557 & & & \\
\hline I feel comfortable expressing my views regarding & pre- & 3,26 & ,764 &,- 593 & $-3,309$ & ,003 \\
\hline $\begin{array}{l}\text { a pressing global problem in front of a group of } \\
\text { people. }\end{array}$ & post- & 3,85 &, 770 & & & \\
\hline I am able to write an opinion letter to a local & pre- & 3,54 & ,793 &,- 179 & $-1,000$ & ,326 \\
\hline $\begin{array}{l}\text { media source expressing my concerns over global } \\
\text { inequalities and issues. }\end{array}$ & post- & 3,71 &, 810 & & & \\
\hline Over the next 6 months, I plan to do volunteer & pre- & 3,21 & 1,031 &,- 357 & $-2,173$ & ,039 \\
\hline & post- & 3,57 & ,920 & & & \\
\hline Over the next 6 months, I will participate in a & pre- & 3,71 & 1,117 &,- 071 &,- 493 & 626 \\
\hline $\begin{array}{l}\text { walk, dance, run, or bike ride in support of a } \\
\text { global cause. }\end{array}$ & post- & 3,79 & 995 & & & \\
\hline Over the next 6 months, I will volunteer my time & pre- & 3,25 & ,887 &,- 071 &,- 420 & 678 \\
\hline $\begin{array}{l}\text { Working to help individuals or communities } \\
\text { abroad. }\end{array}$ & post- & 3,32 & ,945 & & & \\
\hline Over the next 6 months, I plan to get involved & pre- & 3,21 & ,876 & 0,000 & 0,000 & 1,000 \\
\hline $\begin{array}{l}\text { With a global humanitarian organization or } \\
\text { project. }\end{array}$ & post- & 3,21 & ,787 & & & \\
\hline Over the next 6 months, I plan to help & pre- & 3,54 & ,962 & ,071 & ,465 & ,646 \\
\hline & post- & 3,46 & ,881 & & & \\
\hline Over the next 6 months, I plan to get involved in & pre- & 3,46 & 999 &,- 036 &,- 238 & 813 \\
\hline $\begin{array}{l}\text { a program that addresses the global } \\
\text { environmental crisis. }\end{array}$ & post- & 3,50 & ,962 & & & \\
\hline Over the next 6 months, I will work informally & pre- & 2,93 & 813 &,- 286 & $-1,769$ & ,088 \\
\hline $\begin{array}{l}\text { with a group toward solving a global } \\
\text { humanitarian problem. }\end{array}$ & post- & 3,21 & ,787 & & & \\
\hline Over the next 6 months, I will pay a membership & pre- & 3,04 & 1,105 & 0,000 & 0,000 & 1,000 \\
\hline & post- & 3,04 & ,999 & & & \\
\hline
\end{tabular}

\begin{tabular}{l|l|l}
$p<0.01$ & $p<0.05$ & $p<0.1$ \\
\hline
\end{tabular} 


\begin{tabular}{|c|c|c|c|c|c|c|}
\hline & & Mean & $\begin{array}{c}\text { Std. } \\
\text { Deviation }\end{array}$ & $\begin{array}{c}\text { Paired } \\
\text { Difference } \\
\text { Mean }\end{array}$ & $\mathrm{t}$-score & $\begin{array}{l}\text { Sig. }(2- \\
\text { tailed) }\end{array}$ \\
\hline \multirow{2}{*}{$\begin{array}{l}\text { Over the next } 6 \text { months, I will contact a } \\
\text { newspaper or radio to express my concerns about } \\
\text { global environmental, social, or political } \\
\text { problems. }\end{array}$} & pre- & 2,32 &, 819 & \multirow[t]{2}{*}{,- 357} & \multirow[t]{2}{*}{$-1,987$} & \multirow[t]{2}{*}{,057 } \\
\hline & post- & 2,68 & ,945 & & & \\
\hline \multirow{2}{*}{$\begin{array}{l}\text { Over the next } 6 \text { months, I will express my views } \\
\text { about international politics on a website, blog, or } \\
\text { chat room. }\end{array}$} & pre- & 3,04 & 1,105 & \multirow{2}{*}{,- 250} & \multirow[t]{2}{*}{$-1,491$} & \multirow[t]{2}{*}{, 148 } \\
\hline & post- & 3,29 & ,937 & & & \\
\hline \multirow{2}{*}{$\begin{array}{l}\text { Over the next } 6 \text { months, I will sign an e-mail or } \\
\text { written petition seeking to help individuals or } \\
\text { communities abroad. }\end{array}$} & pre- & 3,29 & 1,049 & \multirow[t]{2}{*}{,- 071} & \multirow[t]{2}{*}{,- 386} & \multirow[t]{2}{*}{,702 } \\
\hline & post- & 3,36 & 1,026 & & & \\
\hline \multirow{2}{*}{$\begin{array}{l}\text { Over the next } 6 \text { months, I will contact or visit } \\
\text { someone in government to seek public action on } \\
\text { global issues and concerns. }\end{array}$} & pre- & 2,43 &, 836 & \multirow[t]{2}{*}{,- 143} & \multirow[t]{2}{*}{$-1,000$} & \multirow[t]{2}{*}{,326 } \\
\hline & post- & 2,57 & ,790 & & & \\
\hline \multirow{2}{*}{$\begin{array}{l}\text { Over the next } 6 \text { months, I will display and/or } \\
\text { wear badges/stickers/signs that promote a more } \\
\text { just and equitable world. }\end{array}$} & pre- & 3,14 & 1,044 & \multirow[t]{2}{*}{,- 429} & \multirow[t]{2}{*}{$-2,714$} & \multirow[t]{2}{*}{,011 } \\
\hline & post- & 3,57 & ,879 & & & \\
\hline \multirow{2}{*}{$\begin{array}{l}\text { Over the next } 6 \text { months, I will participate in a } \\
\text { campus forum, live music, or theater performance } \\
\text { or other event where young people express their } \\
\text { views about global problems. }\end{array}$} & pre- & 3,57 & ,959 & \multirow[t]{2}{*}{,- 036} & \multirow[t]{2}{*}{,- 197} & \multirow[t]{2}{*}{846} \\
\hline & post- & 3,61 & ,832 & & & \\
\hline \multirow{2}{*}{$\begin{array}{l}\text { If at all possible, I will always buy fair-trade or } \\
\text { locally grown products and brands. }\end{array}$} & pre- & 4,07 &, 858 & \multirow[t]{2}{*}{,- 036} & \multirow[t]{2}{*}{,- 273} & \multirow[t]{2}{*}{,787 } \\
\hline & post- & 4,11 & ,737 & & & \\
\hline \multirow{2}{*}{$\begin{array}{l}\text { I will deliberately buy brands and products that } \\
\text { are known to be good stewards of marginalized } \\
\text { people and places. }\end{array}$} & pre- & 3,79 & ,876 & \multirow[t]{2}{*}{,071 } & \multirow[t]{2}{*}{,493 } & \multirow[t]{2}{*}{,626 } \\
\hline & post- & 3,71 & ,854 & & & \\
\hline \multirow{2}{*}{$\begin{array}{l}\text { I will boycott brands or products that are known } \\
\text { to harm marginalized global people and places. }\end{array}$} & pre- & 3,71 & ,854 & \multirow[t]{2}{*}{,107 } & \multirow[t]{2}{*}{,648 } & \multirow[t]{2}{*}{, 523} \\
\hline & post- & 3,61 & ,916 & & & \\
\hline
\end{tabular}

\section{\begin{tabular}{l|l|l}
$p<0.01$ & $p<0.05$ & $p<0.1$
\end{tabular}}

